\title{
The Importance of Empathic Listening Skills in Turkish Learning of Foreign Students
}

\author{
Aysegul Nacak ${ }^{1 *}$ (iD
}

${ }^{1}$ Girne American University, CYPRUS

*Corresponding Author: aysegulnacak1985@hotmail.com

Citation: Nacak, A. (2021). The Importance of Empathic Listening Skills in Turkish Learning of Foreign Students. Mediterranean Journal of Social E Behavioral Research, 5(2), 35-40. https://doi.org/10.30935/mjosbr/10917

\begin{abstract}
Language is one of the most important tools in people's lives. It is the ability of individuals to communicate with people who know their own language in their social lives and it is shaped with people around them when they enter a society while another language is spoken. Language is also important to interact with them, to empathize and to understand / be understood and act together depending upon mutual understanding of each other and using a common language. Mother tongue is on the other hand defined as the first language acquired by individuals in their family and the society in which they grew up. The mother tongue can be acquired, and the foreign language can said to be learned. The mother tongue of Turkish societies is Turkish;also the first language to be accepted as an official language for Turkish Republic as well. Turkish, on the other hand, is a language with a deep-rooted culture dating back to ancient times. The functions of language or mother tongue are also to be able to realize effective communication in life. Effective communication can be achieved by understanding the feelings and thoughts of the other person, that is, by listening to them empathetically. When another language is to be learned, one of the most important criteria for the individual to acquire empathic listening skill is the cultural structure of that language. Learning only the grammar of a foreign language and four basic language skills alone is not enough for an empathic communication; The empathic dimension of listening, which is one of these four basic language skills, should also be culturally understood. Because the importance of empathic communication skill cannot be denied in using and understanding languages correctly. Teaching Turkish to foreigners has been increasing especially in recent years. Therefore, the relationship between mother tongue-foreign language-empathic communication skills, with students learning foreign languages are considerably important. In this regard, foreign individuals who learn Turkish presented in the article are at the same time get to know not only Turkish but also the Turkish culture. This study is a qualitative research and it tries to examine the benefit provided by foreigners who learn Turkish to use this language in the most effective way. Learning and using Turkish effectively is founded out to be related with getting to know the culture and gaining empathic listening skills.
\end{abstract}

Keywords: language, mother tongue, communication, foreign language education, empathic listening

Received: 4 Apr. $2021 \bullet$ Accepted: 9 May 2021

\section{INTRODUCTION}

Language is a communication tool called the art of understanding and narration and it is the first of the founding elements that ensure agreement between people. Language is a very powerful, magical order that we use in communication, verbally and in writing, that we start to acquire when we are born, directly specific to human beings; it is a system of thinking and transferring what is thought. "Beginning from birth, human beings are surrounded by a mass of values formed by the knowledge that exist in the society in which they live, the behavior patterns among people, beliefs and theories. All these values are transmitted to individuals through the language that carries them. The child opens his eyes in a language that surrounds him. This is his native language. It acquires the sound features of that language, and the consciousness of that language is awakened by means of comprehension and expression. This is the basic duty of language. Language is a tool that provides comprehension and expression" (Adall, 1983).

Language has both individual and social aspects, functions. Each person develops a language and expression suitable for his education, level of thinking, perception level and character. For example, the ability to form sentences with abstract or concrete words, to use long or short sentences, to make similes, to speak confidently or timidly... These situations enable individuals to speak in harmony with the environment they live in. For this, it will be very useful to learn a language by learning the culture of a language. A person who communicates in the society he lives in by adopting a habit of habitual speaking with a broken language will not be able to express himself correctly and prevent himself from being understood correctly. The more the individual's level of thinking about the society he lives in, the 
more his language ability develops, so he can express himself correctly in every environment, transfer his knowledge successfully, make eye contact with people easily, and tell what he wants to say by giving a message that is suitable for his purpose without being verbal. Captures the advantage of good communication skills in both his immediate environment and career environment.

With the rapid development and advancement of technology in recent years, people's feelings of curiosity have increased and they have reached the desire to reach whatever they think makes the most beautiful, the best, the most pleasant one happy; For this reason, people want to reach other worlds other than their own worlds, to establish a life in other countries, to know other cultures, etc. The main reasons for these are the artificial abolition of the borders between countries in this way, it is now very correct to call the world a seriously small village. In this context, individuals need to learn a language other than their mother tongue. Arslan (2004) stated that Ziya Gökalp was the first thinker who sought a response to the concept of "culture" in Turkish literature and called it "hars" and that his definition of culture was "language, religion, literature, fine arts, law, economy, tradition and "The sum of institutions such as customs, customs, etc. is called culture." When learning a foreign language, the culture of that language is actually recognized. In all countries, different foreign languages are either integrated into education programs or, in cases where these are not sufficient, different units provide training / courses for foreigners to learn these foreign languages separately according to demand. Many adults also learn another foreign language without age restrictions at these course locations. As Moeller and Abbott (2018) underlines that students in language classes who access the manifestations of another culture are able to develop the ability to use language appropriately in social situations, and gain insights into others' perspectives and worldview.

The concept of mother tongue (first language) was defined by Topaloğlu (1989: 24) in the Glossary of Grammar Terms as: "The language that a person acquires first from his mother and other family members, then from the social environment in which he lives, and that provides communication between himself and the society". In this respect, we can define the concept of mother tongue as the language that we first started to acquire from the mother's womb, express ourselves most strongly and perceive it in the strongest way. Our mother tongue is Turkish. Turkish is also an agglutinative language with a long history. Learning Turkish means learning a wide range of cultural geography.

Foreign language (second language), "Whatever language a person knows, that foreign language, which can also be Turkish, will now become a part of it and its value. Therefore, that language will love and praise the culture of the nation." (Gülay, 1988, p. 34). Barın (2004) expresses that learning a foreign language means meeting a language and culture other than one's mother tongue. "Foreign language teaching aims to open up to multiculturalism on the one hand and to live together in peace and tranquility in multicultural communities on the other hand. Today, the main purpose of this foreign language understanding, more precisely the intercultural communicationoriented approach, is to gain intercultural communication skills"(Işık, 1996, p.7). For a foreign language (second language), it can be said that it is the second language that a person acquires through learning other than his mother tongue; Learning a second language is a very important communication process that transfers the cultural accumulation of a society to the foreigner who learns it. Pektekin (1990, p. 69), on the other hand, states that "Learning a foreign language means entering into a dialogue with a foreign culture.

This trend, which makes intercultural comparison the basis of foreign language teaching, states that learning a foreign language is considered as a reckoning with one's own culture and with a foreign culture". As can be seen from the definitions made in this context, learning only the alphabet of that language and learning the grammatical rules while learning a second language; It seems that learning body language, gestures and gestures, or tone of voice will be incomplete for correct communication of that language. If the culture of the language learned is presented to the person at the learning stage, then full communication can be established. Because at this stage, the individual starts to learn the way of empathic listening.

Listening is to understand a person's feelings and thoughts, to perceive them and to provide them with feedback. The act of listening involves complex affective, cognitive, and behavioral processes. (Yurko \& Styfanyshyn, 2020) It consists of three dimensions: sensing, processing, and responding. Sensing refers to the receiving of messages; processing refers to events that take place in the mind of the listener such as organizing and assessing the significance of information; and responding involves recognizing receipt of messages.(Drollinger, 2018) Sever (1995, p.15) listening, "is the most basic way of communication and learning. In the communication process the things transmitted by the 'source' must be shared by the 'receiver'. The recipient's ability to gain new experiences, on the other hand, is closely related to their accumulation in listening skills. Perceiving, understanding, and interpreting the information, news, attitudes, feelings and thoughts that are turned into words by the source requires some knowledge, skills and habits. The listening comprehension skill gained during the mother tongue acquisition period can be improved with empathic listening skill while learning a foreign language. According to Demirel (2002), listening is the activity of "understanding the message that the speaker wants to give and reacting to the stimulus in question." This shows that listening is done deliberately. Because everything heard does not mean listened. Robertson (2004) states that people do not have sufficient listening efficiency. Hearing is all the sounds that a person hears around him without any effort; this is also a physiological feature of man. If there is no obstacle in our ear organs, people hear many sounds and noises in their lives, and only some of these sounds can be perceived. For example, we can hear the voice of a friend when we are around. However, this is not a stand-alone listening activity. When we focus our attention on our friend and make an effort to understand his feelings and thoughts, the listening process begins consciously. Even from this perspective, listening is one of the most important communication skills.

Communication, on the other hand, according to the Dictionary of Turkish Language Association (2005), "Transfer of feelings, thoughts or information to others in any way imaginable, communication, communication, communication." It is defined as. Communication is the art of understanding each other rather than a process of persuasion. Communication becomes meaningful when it is bi-directional, that is, by focusing attention, it is strengthened by being able to check whether or not we understand / understand the message we give / receive from the other person / person. At this stage, it only becomes meaningful. With communication, people actually know what, when, where, how and to whom to say. In this context, we can say that the starting point 
Table 1. Some proverbs and idioms related to communication and active listening

\begin{tabular}{|c|c|c|c|}
\hline $\begin{array}{l}\text { Some of the Proverbs and Idioms on } \\
\text { Empathic Listening and / or } \\
\text { Communication }\end{array}$ & Definition & $\begin{array}{l}\text { Some of the Proverbs and Idioms on } \\
\text { Empathic Listening and / or } \\
\text { Communication }\end{array}$ & \\
\hline $\begin{array}{l}\text { 'Kulak arkasina atmak.' (Throw behind } \\
\text { the ear) }\end{array}$ & Listen without regard to what is said & $\begin{array}{l}\text { Lafla pilav pişerse deniz(dağ) kadar yağı } \\
\text { benden. }\end{array}$ & $\begin{array}{l}\text { If speaking were able to accomplish } \\
\text { things, the biggest things would be } \\
\text { successful by uttering the biggest words. }\end{array}$ \\
\hline $\begin{array}{l}\text { 'Akıllı, söylemeden düşünür, akılsız } \\
\text { düşünmeden söyler.`'(She thinks } \\
\text { without thinking and speaks without } \\
\text { thinking.) }\end{array}$ & $\begin{array}{l}\text { In order not to regret later, the word to } \\
\text { be said and the work to be done should } \\
\text { be carefully considered first. The word } \\
\text { spoken without thought, the work } \\
\text { done, may be objectionable; It can cause } \\
\text { harm }\end{array}$ & $\begin{array}{l}\text { 'Cahile söz (laf) anlatmak, deveye } \\
\text { hendek atlatmaktan güçtür(zordur). } \\
\text { (Speaking of ignorance is difficult } \\
\text { (difficult) than ditching a camel.) }\end{array}$ & $\begin{array}{l}\text { No matter how hard you try, you cannot } \\
\text { ditch the camel. Speaking ignorantly is } \\
\text { more difficult than that. }\end{array}$ \\
\hline $\begin{array}{l}\text { 'Az söyle, çok dinle.' (Say less, listen } \\
\text { more.) }\end{array}$ & $\begin{array}{l}\text { If the person spoke little, he did not } \\
\text { bother those around him; and less } \\
\text { wrong. Learns a lot by listening a lot }\end{array}$ & $\begin{array}{l}\text { İki dinle(bin işit) bir söyle. (Sir söyle iki } \\
\text { dinle). }\end{array}$ & $\begin{array}{l}\text { It is not right to talk too much. Speaks } \\
\text { too much, speaks unnecessary, false } \\
\text { words. If the other person says two, ten, } \\
\text { a hundred, say one. In order to be able } \\
\text { to respond on the spot, you should not } \\
\text { be thrown away and listen to what is } \\
\text { being said for a long time. }\end{array}$ \\
\hline $\begin{array}{l}\text { Boğaz dokuz (kork) bölümdür. (The } \\
\text { throat is composed of nine sections.) }\end{array}$ & $\begin{array}{l}\text { Before we say a word, we have to pass } \\
\text { my throat once in each knuckle, think } \\
\text { about the result of this, correct the } \\
\text { unsuitable aspects so that we have to } \\
\text { think over and over again (to the last } \\
\text { node), then say it. }\end{array}$ & $\begin{array}{l}\text { Önce düşün, sonra söyle. (Think first, } \\
\text { say later.) }\end{array}$ & $\begin{array}{l}\text { There are a lot of times we later } \\
\text { regretted the words we said without } \\
\text { thinking about it and said I wish I } \\
\text { hadn't. In order not to fall into such a } \\
\text { situation, we need to think long and } \\
\text { hard before saying a word. }\end{array}$ \\
\hline $\begin{array}{l}\text { Yağmur olsa kimsenin tarlasına } \\
\text { yağmaz.( If there was rain, it wouldn't } \\
\text { rain on anyone's field.) }\end{array}$ & $\begin{array}{l}\text { Does not like to talk to anyone, } \\
\text { disconnected from communication. }\end{array}$ & $\begin{array}{l}\text { Dilinden anlamak.(Understanding from } \\
\text { the language.) }\end{array}$ & $\begin{array}{l}\text { Describing what you want to tell about } \\
\text { the sounds a creature makes or its } \\
\text { behavior }\end{array}$ \\
\hline İletişim kurmak (Getting contact) & Mutually understand each other & $\begin{array}{l}\text { Don yağının tortusu gibi kalmak.( } \\
\text { Staying like the residue of tallow.) }\end{array}$ & $\begin{array}{l}\text { Being indifferent and dull without } \\
\text { communicating with those around } \\
\text { them. }\end{array}$ \\
\hline
\end{tabular}

of communication is that the individual knows himself and develops behavior accordingly. We cannot think of language and communication separately.

Effective communication is by understanding the other person, that is, by listening in an empathetic way. For this reason, trying to understand first and then trying to be understood would be the best way. This principle is the indispensable principle of effective communication between individuals in the society. In this context, the individual's self-knowledge means being aware of his / her own perception, interpretation ability, sense of reflection and desires. An individual who is aware of the feelings and thoughts of the other person can understand what kind of inner world his behavior reflects and what his experiences and experiences are. Personality differences of lack of empathic listening, educational differences, sensitivities, etc. It is stated that it is based on its causes.

\section{THE IMPOR TANCE OF EMPATHY AND EMPATHIC LISTENING IN COMMUNICATION}

Empathy is the natural understanding of the feelings and thoughts of the person by putting himself in the place of the other person. Sharing one's feelings, thoughts and desires is an empathy. (Pek, et al. 2001). Empathy is a commonly used but poorly understood concept. Sympathy is often confused with interrelated concepts such as pity, identification, and replacement. Empathic skill, on the other hand; It is an individual's ability to correctly understand other people's perceptions and attitudes and to give feedback (Pek, et al. 2001). There are three basic elements in empathy. These; "To look at the events from the point of view of the other person", "to understand the feelings and thoughts of the person" and "to show the other that we understand". Empathetic listening is a tool for empowerment because it allows students to feel heard and understood in a way they may not in the typical public speaking classroom. (Fabian,2019)

Dökmen (2012, p.157), "For effective interpersonal communication, individuals need to develop their empathy skills. In short, empathy is defined as the individual's thinking and feeling like someone else by putting himself in his place ". "Considering the interpersonal relations, we send very important messages to the person or people we face with listening. Listening is a powerful way to show that we accept and respect the existence of another person" (Telman \& Unsal, 2005). It is known that empathy has two aspects, cognitive and affective. Understanding the other person, the cognitive part; Understanding what the other person is feeling or establishing affective communication is the affective part. Empathic skills also increase with education.

Since listening is a conscious action, these expressions are directly related to empathic listening, since it means understanding the feelings and thoughts of the other person. In this context, empathic listening means conscious listening in order to be able to perceive, understand and perceive by putting ourselves in the place of the other and is the key to effective communication. According to Nichols (2016, p.100), "Empathic responses are measured, they are generally silent, they just watch and encourage the speaker without directing them to the depths of their experience". Knowing empathic listening and, most importantly, reflecting this on behaviors is an indicator that 
communication with the other person will be healthy. In order to establish correct and effective communication, we must be able to listen to others with "empathic listening". Empathic listening is actually the basic building block of effective listening and therefore effective communication.

Empathic listening creates a suitable framework for the speaker to express himself or herself better. The acceptance of his feelings and thoughts in their natural form without any judgment or criticism gives the speaker great confidence. The speaker, who thinks that his feelings and thoughts are understood, also feels comfortable in this environment of trust and expresses the event or situation he experienced in all dimensions (Cihangir Çankaya, 2011, p.99).

The way individuals listen to the other person may be different. We can find these differences in proverbs, idioms, and quotations in our native language. The definition of empathic listening is the phrase "listening with your ears". Pure attention means to listen to the other person in order to understand and perceive them correctly.

Below are some proverbs and idioms about Communication and Active Listening in Turkish (Aksoy, 2008).

As you can see, our mother tongue is also rich in terms of idioms and proverbs. These proverbs and idioms are also part of introducing our culture.

Some Methods / Approaches Used in Teaching Turkish for Foreigners

1.Natural Method,

2. Grammar-Translation Method,

3. Direct Method,

4. Audiovisual Method,

5. Auditory-Linguistic Method,

6. Elective Method,

7. Cognitive Method,

8. Cultural Approach

9. Action-Oriented Approach,

10. It is a Communicative Approach.

"Language has an important place in processes such as communicating, expressing feelings and thoughts, interacting, integrating with the outside world, and transferring culture. Language affects characteristics such as developing the capacity of the individual to the fullest, solving complex problems, scientific thinking, having various values, creating a wider world view. This situation brought to the agenda that language skills should be developed throughout life rather than being limited to education at school. For this reason, great importance is attached to developing language skills in many countries, and new approaches and methods are constantly being applied. “ (Güneş, 2011, p.124).

Although all of these methods are a whole, the Communicative and Action-Oriented Approach, which will be examined in detail below, will achieve the goal of the article.

\section{COMMUNICATIVE APPROACH AND ACTION- ORIENTED APPROACH}

Some of the commonly used methods for foreign language education have language - culture - communication approaches. Considering teaching Turkish, it is thought that it is the best choice to apply Communicative and Action-Oriented approaches in teaching Turkish at the same time for those who choose to learn a foreign language as their preference. One of the most effective approaches of empathic listening skill in foreign language teaching is the "Communicative Approach". Puren (2004) states that this approach is formed by adding the communication dimension to the grammar, vocabulary and culture approaches. This approach is "a method based on communication rather than grammar and spelling." (Akpınar Dellal \& Çınar, 2011, p.24). It can be said that it is a method applied especially for people who learn foreign languages, who want to learn a language to meet their needs in natural life processes. It is a method with a lot of proverbs, idioms, examples from real life belonging to culture, uses that can be useful in daily life. According to Puren (2004), one of the main features of the communicative language approach is that it deals with both functional and structural features of language. This type of approach focuses on developing four basic language skills, namely listening, reading, speaking, and writing, and all of these are determined according to the linguistic needs of the learner.

The communicative approach is a major revolution for language teaching. Because it emerged with the idea of seeing that the language does not only consist of structures and to teach by combining grammar and functions. According to this approach, language does not serve anyone when its communicative functions are not taken into account (Yaylı \& Yaylı, 2009, p.16).

Another approach to be considered is "Action-Oriented Approach". This approach is an important one developed by the Council of Europe. According to this approach, Günday (2013, p.317) states that foreign language learners should be educated socio-culturally in both their mother tongue and their target languages, and it is possible to establish effective communication and joint actions between these people, to acquire intercultural awareness and to associate different cultures. According to Ağıldere (2008, p.130), the healthy development of intercultural communication skills is directly related to the individual's ability to recognize different cultures and establish intercultural relations.

In the Communicative Approach, the teaching or learning of the culture of the language to be learned is a type of approach that is aimed at the correct understanding and transfer of cultural information in communication, and empathic listening skill is effective. It is not only for the formation of a common culture, but also for the creation of a collective action culture based on everyone's individual culture, and on the other hand, it aims to use everyone's culture in terms of knowledge, practice, life skills and action (Perrichon, 2008). Using the communicative approach, the teacher is not limited to the textbook. Temizöz (2008) stated that real resources are used in this approach, that resources such as newspaper and magazine articles, poems, recipes, handbooks, videos, news bulletins, telephone directories can be used in various ways; it states that the textbook is only a starting point, a tool. 


\section{CONCLUSION}

Language considered as a living tool, is part of the culture that constitutes it, it is its fascination. In this sense, learning a foreign language and learning the culture of that language is one of the most important features. In short, learning a foreign language means getting to know other cultures. A foreign language is important because it helps people to learn what is happening in the world. It actually makes people citizens of the world. Knowing a language broadens one's horizons and makes one more questioning and a critic person. Mother tongue like Turkish, has a deep-rooted richness of expression in which feelings and thoughts can be expressed very effectively. The number of foreigners who learn Turkish as a foreign language and want to learn is also increasing day by day. It quickly became one of the most widely learned foreign languages in the world. There is no doubt that foreign language teaching is not just about grammar teaching. A teaching method blended with culture, which should include all four basic language skills It is only possible to establish a balanced and effective communication if these four basic language skills are taught in a balanced way. For foreign language learners, proverbs, idioms, aphorisms, synonyms, figurative expressions should be used abundantly in texts related to the related culture. In this regard, trainers should be their own supporters of this learning process. From this point of view, it is very important for the instructors to have the competence to understand foreigners and to establish empathic communication with them. Acting together with students makes it necessary to understand and share cultural behavior.

Appropriate learning approaches are needed for effective foreign language teaching. It is known that there are many approaches in this regard. However, the most preferred approaches today are Communicative and Action-oriented approaches. These two approaches are based on the student, and are the ones that keep communication at the forefront. Listening has a very important place in our lives. As Sethi \& Seth (2009) underlines both the form and the content of the communication reflect the personal characteristics of the individuals as well as their social roles and relationships. Especially if we take the person in front of us seriously and consciously listen to him while making an effort to understand him, the person in front of us actually feels more valuable, and this can be considered as a factor that facilitates communication. In this context, the empathic listening skill in the Communicative Approach is a great point.

Hartley (2002), on the other hand, stated that individuals do not emphasize enough on the listening skill that they think they have acquired from birth. People who think that lack of communication or communication problems often forget that the real source of the problem is their inability to listen empathically. Because just to hear someone, not to understand; easier than communicating with empathic listening. Because when you understand, people should change in a positive way. Foreigners will also get to know our culture with empathic listening skills while learning our mother tongue (Britain,2010).

Suggestions for the development of empathic listening skill in foreigners' Turkish learning can be listed as follows:

- One should be aware that listening and hearing are not the same concepts in effective communication.

- Proverbs and idioms in our native language for those who learn the language in the listening process, to help them recognize the culture to which the language belongs and make sense of the language Synonym, homonymous and figurative expressions should be included in literary texts and practices that are listened to.

- Understand what empathy is and the role of empathic listening in communication while listening.

- It should be stated that while learning a language, empathic listening will help individuals in the environment to be fully understood; should be assimilated.

- The level of realization of the listening performed in an empathetic manner should be checked by asking appropriate questions for the audience.

- The trainers should also be individuals with strong communication skills, high empathy skills, and very good knowledge of foreign language learning approaches; and should not leave students' questions unanswered.

- Instructors who teach a foreign language must first themselves be an empathetic listening or listener model.

Author contributions: All authors were involved in concept, design, collection of data, interpretation, writing, and critically revising the article. All authors approve final version of the article.

Funding: The authors received no financial support for the research and/or authorship of this article.

Declaration of in terest: Authors declare no competing interest.

Data availability: Data generated or analysed during this study are available from the authors on request.

\section{REFERENCES}

Adalı, O. (1983). Ana dili olarak Türkçe öğretimi üzerine [Teaching Turkish as a mother tongue]. Turkish Language/ Türk Dili (379380), 31-39.

Ağildere, S. T. (2008). Kültürlerarasi iletişimde eylem odakli yaklaşim: İstanbul Saint-Joseph Lisesinin Türk öğrencileri (1870-1905) [Action-oriented approach in intercultural communication: Turkish students of Istanbul Saint-Joseph High School (18701905)]. Atatürk Üniversitesi Kazım Karabekir Eğitim Fakültesi Dergisi/Ataturk University Journal of Kazım Karabekir Education Faculty, (18), 125-134.

Aksoy, Ö.A. (2008). Atasözleri ve deyimler sözlüğü [Proverbs and phrases dictionary]. Inkılap Bookstore.

Arslan, M. (2004). Ziya Gökalp’te kültür ve uygarlık anlayıșı. Türkiye’de sosyoloji [Understanding of culture and civilization in Ziya Gökalp. Sociology in Turkey]. Ziya Gokalp Symposium, Istanbul University Faculty of Letters Department of Sociology.

Barın, E. (2004). Yabancılara Türkçe öğretiminde ilkeler [Principles in teaching Turkish to foreigners]. Hacettepe Üniversitesi Türkiyat Araştırmaları (HÜTAD)/Hacettepe University Turkish Studies, (1), 19-30

Britain, D. J. (2010). Language and space: The variationist approach. In P. Auer \& J. E. Schmidt (Eds.), Language and space: An international handbook of linguistic variation (vol. 1, pp. 142-162). De Gruyter Mouton. https://doi.org/10.1515/9783110219166.1.69

Cihangir Çankaya, Z. (2011). Kişilerarası ilişkiler ve iletişimde dinleme [Interpersonal relations and listening in communication]. In A. Kaya (Ed.), Kişilerarası ilişkiler ve etkili iletişim. PEGEM Publications. https://doi.org/10.14527/9786052414507.04 
Demirel, Ö. (2002). Türķ̧e öğretimi [Turkish teaching]. Pegem Academy Publishing.

Drollinger, T. (2018). Using active empathetic listening to build relationships with major-gift donors. Journal of Nonprofit \& Public Sector Marketing, 30(1), 37-51. https://doi.org/10.1080/ 10495142.2017.1326336

Fabian, J. (2019). Empowering Public Speaking Students through Consultant Training in Empathetic Listening. Communication Center Journal, 5(1), 189-191.

Gülay, N. (1988). Yabanclara Türkçe öğretiminin politik önemi [Political importance of teaching Turkish to foreigners]. TÖMER Dil Dergisi/TÖMER Language Journal, 1, 34-36.

Günday, R. (2013). Çok dillilik ve çok kültürlülük bağlamında yabancı dil öğretimine toplumdilbilimsel yaklaşım [Sociolinguistic approach to foreign language teaching in the context of multilingualism and multiculturalism]. Turkish Studies, 8-10, 313330. https://doi.org/10.7827/TurkishStudies.5121

Güneş, F. (2011). Dil öğretim yaklaşımları ve Türkçe öğretimindeki uygulamalar [Language teaching approaches and applications in Turkish teaching]. Mustafa Kemal Üniversitesi Sosyal Bilimler Enstitüsü Dergisi/Mustafa Kemal University Journal of Social Sciences Institute, 8(15), 123-148.

Hartley, P. (2002). Interpersonal communication. Routledge. https://doi.org/10.4324/9780203019719

Moeller, A. J., \& Abbott, M. G. (2018). Creating a new normal: Language education for all. Foreign Language Annals, 51(1), 12-23. https://doi.org/10.1111/flan.12310

Nichols, M. P. (2016). Dinleme Sanatı [The Art of Listening] (D. Gunkut, Trans.). Kuraldıșı Publishin.

Pektekin, Ç., Buzlu, S., Sönmez, Y., Batmaz, M., \& Sever A. (1990). Psikiyatri hemşireliği dersi alan öğrencilerin bu dersin uygulanması sonucunda beklentileri ve bu beklentilere ulaşıp ulaşmadıklarının araștırılması [Investigating the expectations of the students taking psychiatric nursing course as a result of the implementation of this course and whether they have reached these expectations]. II Ulusal Hemşirelik Kongresi/II National Nursing Congress, Izmir, Turkey, 12-14 September (pp. 444-451).
Perrichon, E. (2008). Agird usage et agird apprentissage en didactique des langues-cultures étrangères, enjeux conceptuels, évolution historique et construction d une nouvelle perspective actionnelle [To act of use and to act of learning in didactics of foreign languages-cultures, conceptual stakes, historical evolution and construction of a new actionoriented perspective] (Doctoral dissertation). Jean Monnet University of Saint Etienne.

Puren, C. (2004). L'evolution historique des approches en didactique des languescultures ou comment faire l'unite des «unites didactiques» [The historical evolution of approaches to language culture teaching or how to unite "didactic units"]. Annual Congress of the Association for the Diffusion of German in France (ADEAF), Clermont-Ferrand Business School, 2-3 November, France.

Robertson, A. K. (2004). Etkili dinleme [Listening effectively]. Hayat Publications.

Sethi, D., \& Seth, M. (2009). Interpersonal communication: Lifeblood of an organization. IUP Journal of Soft Skills, 3.

Sever, S. (1995). Türkçe öğretiminde tam öğrenme [Complete learning in Turkish teaching]. Anı Publishing.

Telman, N., \& Ünsal, P. (2005). İnsan ilişkilerinde iletişim [Communication in human relations]. Epsilon 128 Publishing.

Temizöz, H. (2008). Yabancı dil öğretiminde dil bilgisi çeviri yöntemi ve iletişimci yaklaşım uygulamalarının öğrencilerin öğrenme becerisi üzerindeki etkisi (Unpublished master's thesis). Inonu University Institute of Social Sciences, Malatya, Turkey.

Yayli, D., \& Yayli, D. (2009). Yabancı dil öğretimi yaklaşımları ve yöntemleri, yabancılara Türkçe öğretimi politika yöntem ve beceriler [Foreign language teaching approaches and methods, teaching Turkish to foreigners, policy, methods and skills]. Anı Publishing.

Yurko, N., \& Styfanyshyn, I. (2020). Listening skills in learning a language: the importance, benefits and means of enhancement. Collective monographs, 38-46. https://doi.org/10.36074/ rodmmrfssn.ed-1.04 